\title{
Building a Public Controversy
}

In the last chapter, we explored the interactions between the three epistemic communities of badger/bTB (animal health, disease ecology and badger protection), policymakers and politicians taking place 'backstage'specialist interactions open to, but rarely scrutinised by, the wider public sphere. ${ }^{1}$ It demonstrated how the backstage manoeuvrings of experts, campaigning interests, policymakers and politicians have been constituted in relation to the 'frontstage' of debates taking place in the wider public sphere. For example, it was after the breakdown of working relationships with policymakers that the Independent Scientific Group (ISG) ensured that their Final Report received wider public attention by giving media interviews, and crafting a clear, quotable message: 'culling cannot meaningfully contribute to the future control of cattle TB in Britain'. ${ }^{2}$ As we saw through the first half of the book, such interactions between policy and public spheres have punctuated the history of badger/bTB. Examples would include Ruth Murray's attempt to prosecute the Farming Minister using his own badger protection legislation; the controversy following the publication of the Zuckerman review in 1980; and the argument between the ISG and David King. At various points in time, the arguments and decisions made in the relatively restricted spaces of scientific and policy fora have been mutually shaped by both mass media coverage and that poorly understood and unpredictable creature, public opinion. This has changed in recent years: as Britain saw the return of badger culling, badger/bTB moved dramatically from the margins to the mainstream of

(C) The Author(s) 2019

A. Cassidy, Vermin, Victims and Disease, https://doi.org/10.1007/978-3-030-19186-3_7 
politics. However, this appears to have been a temporary shift. Following a brief 'storm' of media interest peaking in 2013, coverage levels have dropped off and have been occluded by bigger political issues, most obviously the highly divisive debate over whether, when and how the UK will 'Brexit'-leave the EU.

This chapter will investigate the interactions of media, politicians, pressure groups, journalists and audiences, who between them have made badger/bTB into a hotly contested issue which receives widespread media attention. In the process, it also addresses a wider question for the sociology and history of science: what makes a knowledge controversy become a public knowledge controversy, and how do controversies affect policymaking? ${ }^{3}$ In today's professionalised sciences, disagreements and controversies are mostly fought out by qualified academics in the relatively constrained fora of journal articles, conferences and personal correspondence. While public controversies between and questioning of experts have become more common over the past fifty years, compared to everyday routines of scientific communication, they are still unusual. ${ }^{4}$ When science does become controversial in public, it is often the implications of new scientific ideas or technologies which are contested, for example as seen in 1990s debates over genetically modified foods. ${ }^{5}$ Less commonly, scientists make and contest knowledge claims in the public sphere instead of or alongside their usual fora of academic journals. This makes scientific uncertainties, changing knowledge and questioning of established ideas publicly visible, with significant implications for policy. A good example would be public controversies over Bovine spongiform encephalopathy (BSE) in the UK during the late 1980s and early 1990s. At this time, policy decisions about BSE and food safety had to be made in the face of deep 'unknown unknowns'-when the properties and existence of the transmitting agent, a molecule called a prion, were utterly unanticipated, and scientific understandings of the disease had to be developed under intense public and political scrutiny. ${ }^{6}$ Public knowledge controversies therefore demonstrate that scientific communication and 'popularisation' are not always one-way processes of communicating established science to wider publics; they are also multidirectional and can contribute to the process of building scientific knowledge. They tend to be driven by a combination of internal factors pushing them out of specialist fora (e.g. rapidly changing situations; communications blocks; disciplinary rivalries); and external factors pulling them into mass media (e.g. the power of a good story; direct risks to people; political implications). ${ }^{7}$ As seen in the BSE case, the uncertainties 
and complexities of 'science in the making' exposed during public controversies $^{8}$ raise critical questions about how 'experts', politicians and policymakers can best work together to make sustainable policy decisions that can work in the long term.

This chapter will examine key contours of British press coverage of badgers and bTB and how it has changed since the middle of the last century, as well as how badger/bTB has come to be framed in mass media. It will then return to the sequence of events recounted in Chap. 6 to explore how badger/bTB has been debated in the frontstage of British policy and mass media. We will explore how the long-standing public concerns of the British badger debate and of bTB have repeatedly been brought together and drawn apart over the past fifty years, as well as how in recent years the two have become tightly linked. There has been a series of key changes in badger protection campaigning, wider political debates and mass media working practices since 2010. I argue that these have all contributed to the mainstreaming, polarisation and politicisation of badger/bTB and its movement from the 'backstage' to the 'frontstage' of British animal health policy. ${ }^{9}$ Finally, we will explore how and why this has happened and speculate on the consequences for the underlying problems which have made badger/bTB into such a notorious policy failure. ${ }^{10}$

\subsection{UK Newspaper Coverage: Some Key Indicators}

The digitisation of newspaper archives has made it easier than ever to use press coverage as a blunt indicator of where and when media pay attention to a given issue, providing insights into changes in the public profile of a topic over time. It has also made it possible to collect a large sample of national press coverage of badger/bTB, which has been analysed alongside the archival material, policy documents and interviews used as sources throughout this research. To this end, three sets of keywords were used to search the digital archives of the Guardian/Observer, Independent, Times, Telegraph, Mail and Mirror (plus their Sunday editions) from 1950 to 2000. They were also used to search the Nexis UK database of modern print media (narrowed to these titles) from 1995 to 2017. The first ('badger' AND 'animal') was designed to capture overall coverage of badgers while excluding the unrelated usage of 'badger' as a verb and as a name. The second ('bovine tuberculosis' OR 'bovine TB') was designed to find coverage of bTB itself; while the third ('badger' AND ['TB' OR 'tuberculosis']) found articles discussing badgers and bTB together. The articles brought up by these searches were downloaded and added to two databases 
(alongside interview transcripts, scans of archival sources and images), before and after the publication of the Krebs report in 1997. This search process also yielded quantitative data about how the British press has covered the issue, which will briefly be presented here. ${ }^{11}$ This quantitative data offers some useful insights into how media coverage of badgers, bTB and the controversy about their connection has changed over the past half century.

The broad trends shown in Fig. 7.1 reflect and confirm the stories surrounding badgers and bTB over the second half of the twentieth century. Early press coverage about bTB focused on the success of the Ministry for Agriculture, Fisheries and Food's (MAFF) Area Eradication Scheme, and the 1960 announcement that the whole country had been 'attested'. ${ }^{13}$ Following this, bTB ceased to be of interest until 1975, when MAFF announced its new research and policy programme addressing the new problem of tuberculous badgers. From then on, most articles mentioning bTB also mentioned badgers, but not necessarily the other way around, as can be seen by the close correspondence between 'bovine TB' and 'badger + TB'. By contrast, 'badger + animal' brought up a broad range of material, including natural history columns,

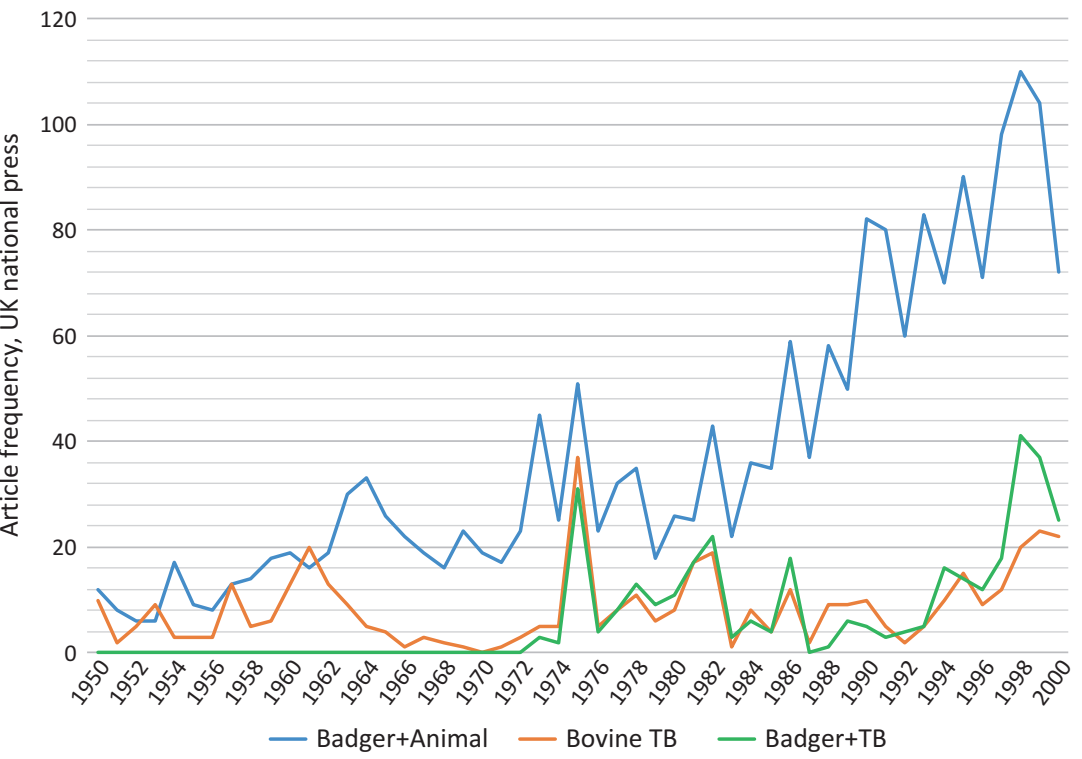

Fig 7.1 UK national newspaper coverage about badgers and bTB, 1950-2000 12 
articles about toys, holidays and the latest adaptation of Wind in the Willows, as well as news coverage relating to $\mathrm{bTB}$. The growing popularity of badgers in the public sphere can be traced from a handful of nature columns in the 1950s, to around eighty articles a year by the 1990s. Peaks in this coverage can be linked to key events in wildlife politics: from the 1955 Scott Henderson report, through the initiation of badger protection campaigns in 1964, to the passing of the Badgers Act in 1973. ${ }^{14}$ Between 1975 and 1986, coverage of badgers and of bTB was linked together, as suggested by the shared spikes in coverage in 1975 (the start of state-led culling) and again in 1982 (when badger gassing ended). ${ }^{15}$ Through the rest of the 1980s and into the 1990s, bTB once again faded from media attention, but badgers received more coverage than ever before. Animal and environmental politics underwent a radical turn at this time, with protests targeted at road expansion, animal experimentation and fox hunting all hitting the headlines. ${ }^{16}$ While substantive policy change on these issues was limited, animal advocates made significant gains on the issue of badger protection, whereby the 1973 Badgers Act was strengthened in 1992 and $1993 .{ }^{17}$ Campaigning leading up to and following this success recreated badgers as a media story in their own right, decoupled from bTB.

As we moved into the twenty-first century, while badgers continued to be covered more than bTB, the two stories started to align once again. Peaks in coverage can be linked to key events in the culling controversy, such as the start of the Randomised Badger Culling Trial (RBCT) trial and the ISG/King controversy in 2007. As the Brown Labour government became weaker and General Election campaigning started, coverage of badger/bTB dropped away as news agendas turned towards mainstream political events. This pattern-of highly episodic coverage, linked to key policy or political events - has been present since the early 1970s in badger/bTB and is highly characteristic of environmental news coverage in general. ${ }^{19}$ Since Labour lost power in 2010 and subsequent administrations have started returning to culling, the media debate has changed. As can be seen in Fig. 7.2, press coverage of badger/bTB started climbing as soon as the incoming Coalition announced its intention to return to culling in 2011 , peaking in 2013 but then returning to mid-2000s levels by the end of 2017 . In the process, media coverage of badgers and of bTB have become more closely linked than ever before. While of course we don't know what will happen next, this post-2010 pattern seems different. Not only was the 2013 peak three 


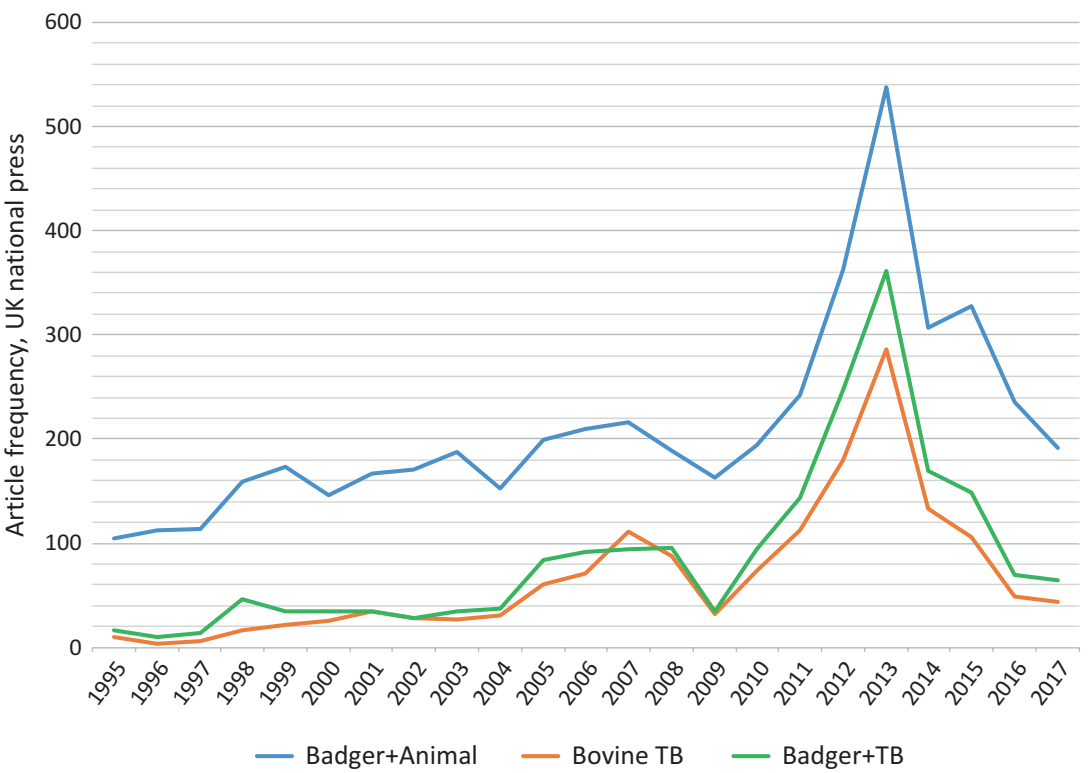

Fig. 7.2 UK national newspaper coverage about badgers and bTB, 1995-201718

times higher than ever before, it cannot be easily attributed to any single event-we will explore the implications of this shift in Sect. 7.4.

British national newspapers operate an overtly politically 'partisan' system, whereby each title has a distinctive and widely understood political orientation, manifesting (for example) as endorsements of political parties during General Elections. As well as differing in their political orientations, newspapers can be further characterised as 'broadsheet', 'mid-market' and 'tabloid' titles, and while the physical differences between newspapers have blurred, it is clear from their content and design that these distinctions are still meaningful (see Table 7.1). These titles cater to significantly different demographics in their readership, particularly in terms of social class, income and political opinions (broadly congruent with those expressed in the newspaper they buy). ${ }^{20}$

Figure 7.3 shows the distribution and amount of coverage of badger/ bTB across the sampled titles, as well as how this has changed over the decades. We can see that, on the whole, badger/bTB has been covered more by right-wing titles than left-wing, reflecting these newspapers' 
Table 7.1 UK national newspapers by format and political orientation

\begin{tabular}{llll}
\hline & 'Tabloid' & 'Mid-market' & 'Broadsheet' \\
\hline 'Left' & Mirror & & Guardian/Observer \\
& Morning Star & & Independent/' $i$ ' \\
'Centre' / no clear & Star & & Financial Times \\
orientation & Sunday People & & \\
& Metro (freesheet) & & Times \\
'Right' & Sun / Sun on Sunday/ & Mail & Telegraph \\
& News of the World & Express &
\end{tabular}

alliances with rural interests. It has been covered far more by broadsheets than tabloids, in a pattern consistent with much scientific and environmental news. ${ }^{21}$ Of more significance is the increasing levels of coverage from the mid-market Mail and tabloid Mirror, particularly since 2010. This is consistent with overall increases in coverage, but also marks a shift in the visibility of badger/bTB to new audiences - and given the higher circulation of these titles, many more people than ever before.

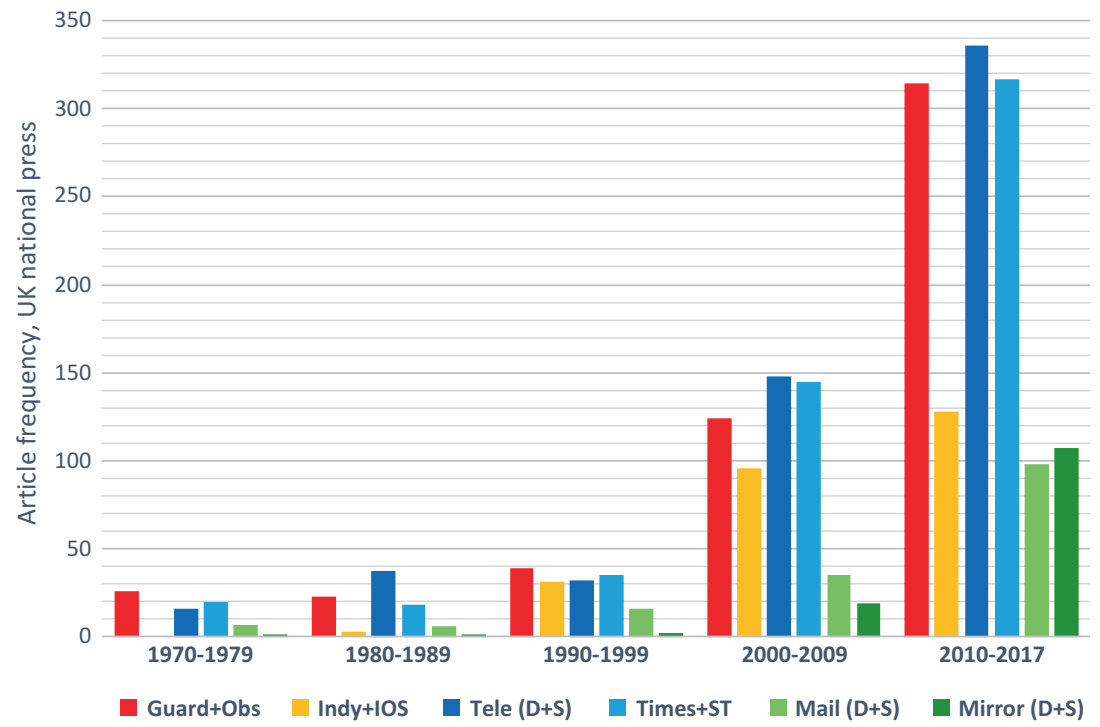

Fig. 7.3 UK national newspaper coverage of badger/bTB, by newspaper title and decade 


\subsection{Agricultural Malaise or Environmental Risk? Media Framings of Badger/BTB}

These bare figures can be fleshed out into a richer picture by looking at the content of newspaper stories about badger/bTB, and particularly at how the issue has been 'framed'. Like historians of medicine, scholars of mass media use framing to analyse how and why particular issues come to the attention of journalists. Their focus tends to be more specific, documenting what gets included in a story and what doesn't, as well as the other issues any given topic is linked to. Media framings are not independently created: instead they are a product of the interactions of advocates' attempts to 'set the agenda'; the judgements of journalists and their editors about what makes a 'good story'; and the preferences of audiences, expressed through sales and increasingly via social media. ${ }^{22}$ Since the 1990s, press coverage of badger/bTB can be characterised as framed in one of two ways: either bTB as an agricultural problem; or badger culling (one of several policies for controlling bTB) as an environmental risk. From the late nineteenth century up to the 1960s, bTB was primarily framed as a (human) public health problem: today risks to human health are only sporadically and strategically discussed. Even so, these framings of badger/bTB are broadly consistent with contemporary 'social representations' of infectious disease, also visible in discussions of diseases like HIV/ AIDS and influenza. Each has clearly identified 'victims, villains and heroes': although who (or what) gets to play each of these roles is different in each framing. ${ }^{23}$

Framing One: An Agricultural Malaise. The first way of writing media stories about badger/bTB should be familiar from the animal health cultures of care explored in Chap. 3. The agricultural frame positions the disease as a resurgent problem severely affecting rural communities and the national economy. Farmers are portrayed as the primary victims (via the loss of their cattle), but also as key professional experts-curiously, they appear much more frequently and prominently than veterinarians. The seriousness of the bTB problem is emphasised by highlighting the zoonotic nature of the disease, and cases of bTB in other livestock (such as llamas), pets and particularly in humans receive a great deal of attention. Despite this, sick cows do not feature, primarily because Britain now rarely sees such cases. The collective slaughter of cattle testing positive for $M$. bovis is emphasised through large numbers: individual cows rarely appear, except (for example) during the 2007 conflict in Wales over the sacred bull 
Shambo. ${ }^{24}$ In line with animal health, the primary symptom of bTB is depicted as its economic impact-upon government, industry and individual farmers. The heroic stories of such farmers - struggling financially but also emotionally with $\mathrm{bTB}$ - provide personal depth to this reporting. They also place the disease into an ongoing narrative about the failures of animal health policy in Britain by connecting current problems to earlier disasters, including the 2001 outbreak of foot and mouth disease (FMD), and further back to BSE. ${ }^{25}$ This links bTB into broader discourses of "marginalised rurality' - the idea that rural perspectives are sidelined in British society-which have become increasingly politicised in recent years:

\begin{abstract}
A beef and sheep producer with arable interests, [incoming NFU President] Ms Batters says farmers are the best custodians of the countryside. But she warns that they are coming under increasing fire from animal rights activists, environmentalists and militant vegans. With consumers more interested in where their food comes from, growers and livestock producers 'cannot afford to be silent', or this void will be 'filled by others', she adds.

Under attack: 'We have seen it with veganism, the badger cull and crop protection. We have been an industry under attack, but reacting to the noise is the worst thing farmers can do', she tells Farmers Weekly. 'Actually, farmers should be really proud of what we do and we need to get those messages across. It's about being more positive, less reactive. ${ }^{26}$
\end{abstract}

Farmers are recognised as having immediate 'experiential expertise', and their first-hand testimony is used in a similar way to that of patients in health reporting. ${ }^{27}$ Yet they are also portrayed as helpless victims, unable to do anything in the face of an unstoppable plague, while 'urban elites' are imagined as indifferent or hostile to the agricultural sector. While veterinarians do feature as legitimate experts dealing with the problem, policymakers and government are deeply distrusted. ${ }^{28}$ When scientists appear they tend to be those supportive of culling, such as Sir David King, and the 'sound science' of such experts is also invoked. Finally, the history of the controversy features, in discussions of the 'Thornbury experiment' of the 1970s, or of earlier culling policies such as gassing. ${ }^{29}$ This demonstrates the strategic role of memory in public controversies: while these past policies are recalled, the compelling reasons for their abandonment are not.

A second victim of bTB, curiously only visible in the agricultural frame, is the sick and suffering badger. The effects of tuberculosis on badgers 
themselves are discussed in some detail, and concerns may be expressed for their suffering. In this framing, killing sick or 'dirty' badgers can be understood as 'taking care' — of sick wildlife, of livestock populations, and of agricultural communities and businesses. ${ }^{30}$ Again in line with animal health and farming cultures of care, the proper role of people in relation to animals and environments should be to restore a 'natural balance' and take on stewardship of the countryside. This natural balance is seen as currently disrupted by overly strict protective legislation, leading to badger populations growing 'out of control'. ${ }^{31}$ More often, the diseased badger is not sympathetic but a 'guilty victim', to be feared, stigmatised and excluded just as we do with human disease victims who lack power. ${ }^{32}$ Badgers were constructed as the chief agents or causes of the bTB epidemic, therefore positioning culling as the most obvious solution to the problem. Today's agricultural framings of bTB have continued to highlight other negative traits of badgers unrelated to the disease, such as violence, predation on other charismatic wildlife such as hedgehogs, disruptive digging and crop destruction. This is emphasised by the frequent reuse of stock images of badgers and cows together: a situation so rare in life that some biologists think that these photographs were staged. ${ }^{33}$ The Bad Badger, present in British culture for centuries, persists and has been transformed by its connection with $\mathrm{bTB}$ into more of a villain than ever before.

Framing Two: An Environmental Risk. The second way of talking about badger/bTB in mass media eclipses and elides infectious disease almost entirely, focusing instead on the favoured 'agricultural frame' solution to bTB: culling wild badgers. This framing tends to downplay disease problems and risks, acknowledging the existence of bTB, but treating it as largely absent - by inference (like its human equivalent), a solved problem of the past. ${ }^{34}$ Sick cattle are never seen, badgers do not become ill and human health risks are not discussed. Up until the ISG's findings were made public, the idea that badgers could carry tuberculosis at all was disputed by many badger advocates. ${ }^{35}$ While the connection between cows, badgers and $M$. bovis is now generally acknowledged, the significance and direction of badger-cattle transmission (compared to cattle-cattle transmission) and the extent to which badgers show clinical symptoms are still heavily contested. Instead, farming practices-including cattle trading, stress, poor hygiene and intensive breeding-are highlighted as the main causes of the resurgence of bTB. These causes are also rooted in accounts of the recent past: in this case the intensification of farming and its 
consequences, for livestock, wildlife and environments. The possibility of avoiding culling in the first place through vaccination has been widely advocated as an alternative, implicitly drawing upon audiences' familiarity with human medical care. ${ }^{36}$

Instead, the focus shifts to badger culling as an environmental risk. The consequences of culling for animals, ecosystems, public order and the popularity of politicians are highlighted. The political and economic risks of culling policies are emphasised, with widespread citation of high policing costs (due to protests) and cost-benefit analyses suggesting culling is not economically viable. Casting government in general or particular politicians as the villains, this framing assumes that 'the public' is strongly opposed to badger culling. ${ }^{37}$ As in the agricultural framing, experiential experts - in the form of animal rescue volunteers and activists-loom large, providing first-hand accounts of badger persecution, as well as heroic stories from the 'front line' of confrontations with those undertaking the Conservatives' new 'trial culls' ${ }^{38}$ Campaigners are attributed the role of experiential and moral experts, not only bearing witness, but also arguing that humans bear the responsibility for preventing and alleviating non-human suffering. Scientists and conservationists are prominently depicted as the professional experts who know most about badger/ bTB. When the Badger Trust opposed the RBCT trial in the 1990s, it drew heavily upon the scientific credentials of their then spokesperson, $\mathrm{Dr}$ Elaine King, and her PhD in badger ecology. ${ }^{39}$ More recently, the ecologists and scientists associated with the ISG-particularly Krebs, Bourne and Woodroffe - have been most prominent, as have famous 'telenaturalists' such as Chris Packham. While specific scientific issues are discussed (such as the perturbation effect, or the consequences of culling for rural ecosystems), science also features as a generalised source of authoritative knowledge. The trope of 'sound science' is fully mobilised by anti-cull campaigners; these tactics are also deployed by scientists themselves when criticising the current culling policy: ${ }^{40}$

The government's chief vet, Christine Middlemiss, said the first cull areas, in Gloucestershire and Somerset, were starting to see drops in TB in cattle, and a full analysis of the data was under way. [ISG scientist Rosie] Woodroffe said: 'Claims that the culls are reducing cattle TB is based on cherry-picking data from a report produced by government scientists. It states explicitly that "these data alone cannot demonstrate whether the badger control policy is effective in reducing bovine TB in cattle".' Middlemiss did not mention 
another cull area, Dorset, where TB rates appear to be rising. Dominic Dyer, the chief executive of the Badger Trust, said: 'This is the largest destruction of a protected species in living memory. By the end of 2018, the government will have spent over $£ 50 \mathrm{~m}$ of public funds killing over 67,000 badgers (since 2013), which could push the species to the verge of local extinction in areas of England where it has lived since the ice age. The badger cull is a cruel, costly and ineffective policy and its continuation is a national disgrace. ${ }^{41}$

While disease victims are absent, the central victim-not of bTB but of human capriciousness-is instead the Good Badger, constructed as a charismatic wildlife species and symbol of idealised British 'nature'. Culling is the human intervention disturbing the 'balance of nature', which in this framing is best achieved by the withdrawal of humans altogether. Badgers are further described as a 'scapegoat' for the bTB problem, enabling farmers, rural interests, policymakers or politicians to avoid addressing a problem implicitly caused by their own actions. ${ }^{42}$ The actual or potential suffering of wild badgers has provided a focus for highly emotive coverage, whether the culling method is free shooting or the more well-established cage-trapping technique. ${ }^{43}$ While gassing has been long abandoned, the rhetoric that badgers are victims of a human inflicted 'holocaust' persists (at times to the dismay of British Jews), emphasising the large numbers killed. Unsurprisingly, these deaths were linked with illegal practices of badger persecution and killing (thought by campaigners to be on the rise), the politics of fox hunting and representations of pro-cull actors as psychologically unbalanced. ${ }^{44}$ In the agricultural framing, British wildlife politics is presented as an aspect of 'urban-rural conflict'. By contrast, in environmental framings opposition to culling is presented as an aspect of a broader ethical outlook, part and parcel of a pro-environmental worldview and identity. Visual images also reinforce the Good Badger-by using wildlife photography these framings immediately recall the long, affectionate history of badgers' appearances on natural history television in Britain. ${ }^{45}$ Cute and literally fluffy animals feature prominently (particularly cubs in animal rescue settings), alongside shocking images of dead and/or suffering badgers: both these tropes draw upon long-standing traditions of animal campaigning. ${ }^{46}$

Not only do these mutually exclusive framings talk about badger/bTB differently, but which media they appear in, and the cast of characters who are interviewed, cited and discussed are very different. The agricultural 
frame appears most often in right-wing national, farming and South West local press and tends to be written by journalists specialising in agriculture, the countryside or by conservative columnists. Key institutional actors include Defra, the NFU, the Farmers' Union of Wales and the National Beef Association. Given their centrality to animal health policy, veterinary associations rarely appear, but practising veterinarians do feature in this coverage. Farmers were the most frequently interviewed source: other individual sources include Conservative Party politicians, celebrities and various members of the British royal family. Stories using the environmental frame tend to appear in left-wing national newspapers and conservation magazines, and are mostly written by environmental and science journalists, or left-wing commentators. Barring Defra, an entirely different set of institutional actors appear, the most prominent of which is the Badger Trust. Considering its small size and tiny budget compared to many NGOs, the Trust's public prominence evidences a continuing tradition of highly skilled media relations. Other actors include the much larger RSPCA and more recently a coalition of animal welfare groups under the banner of 'Team Badger'. Instead of farmers and vets, we see animal rescue volunteers, protesters on marches, and activists directly disrupting culling. Since founding his Save Me Trust, the rock star Brian May has become a key source, and a wave of other celebrities have appeared in the environmental frame. While most coverage has used one of these two framings, some articles have sought to take a more traditionally journalistic, neutral stance, in which both were deployed, using the flip from one to the other as a narrative device. While publics' knowledge and views of badger/bTB are less well studied, similar framings can be discerned in social media and other online fora focused on the topic. ${ }^{47}$

\subsection{Constituting and Contesting Badgers, bTB ANd Culling}

Throughout this book, I have used 'badger/bTB' as a shorthand for the central question under debate in this public knowledge controversy-Do wild badgers carry and pass bTB to domestic cattle, and if so, what should be done about it? As we have seen, over the past fifty years, it has taken a lot of work to bring the previously separated issues of badgers and bTB together into the single issue we see today. Research on environmental and public communication has shown how journalists, audiences, campaigners, 
politicians and experts of various sorts work together to constitute an issue into something that is paid attention to in the public sphere. This involves making and contesting knowledge claims; writing (and convincing editors to publish) pieces in media; and taking on board (or ignoring) coverage about the topic at hand. ${ }^{48}$ In turn, media debates can set, shape, build and break political and policy agendas, perhaps increasingly so in an era where policy actors use coverage as a proxy for wider public opinion, and campaigners put huge resources into gaining it. ${ }^{49}$ Dramatic events, claims, counter-claims and appealing stories attract coverage and draw audience attention not only to the topic but to the various actors' framings of the issue-as demonstrated above. Others with differing views respond with their own counter-claims, which may or may not be persuasive. In the longer term, this is how political, social, scientific and environmental issues become constituted, reconstituted and dissolved in the 'public arenas' of mass media. ${ }^{50}$ Having explored the general characteristics of contemporary $\mathrm{UK}$ media coverage of badger/bTB, the rest of this chapter will trace the public constitution and development of badger/bTB in the long term. It will return to the sequence of events recounted in Chap. 6; but will shift the focus to the 'frontstage' of policy debates as they have played out in mass media. As we will see, while the key events are the same, the details and dynamics of the debate have been very different: subtle rivalries and detailed interpretations of evidence are replaced by dramatically performed protests and emotive rhetorical flourishes.

As suggested by the data in Fig. 7.1, up until the 1990s, the distinct issues of badger protection and of bTB control came together and moved apart several times in the 'frontstage' of the debate. ${ }^{51}$ When it was considered at all, bTB provided a classic narrative of the triumph of modern (veterinary) public health programmes over disease-until it was connected to badgers. By contrast, the public story of the badger was one of increasing visibility, initially through popular natural history across multiple media forms, and then through the energetic media work of badger protection campaigners, drawing in a diverse coalition of actors, including amateur naturalists, professional field biologists, animal welfare campaigners, the Women's Institute (WI) and politicians across party lines. They successfully reframed the older British 'badger debate' in relation to public concerns over environmental damage and the politics of wildlife welfare. This meant that by the time the news of tuberculous badgers broke, it was reported in terms of concern for wildlife rather than cattle: the initial news triggers were the passing of protective legislation and Ruth Murray's 
attempt at prosecuting the Farming Minister. ${ }^{52}$ Coverage of bTB as animal health was largely confined to specialist contexts-agricultural correspondents and local and farming press. ${ }^{53}$ From this point onwards, bTB was mostly reported in terms of badger protection, while badger protection continued to be covered in addition to bTB.

Given that media were foregrounding farmers' illegal 'gassing' of badgers, and that naturalists had already established themselves as accessible, articulate and authoritative experts on the matter, it was relatively easy for them to set the public agenda on bTB ${ }^{54}$ MAFF tried to argue that their research was 'aimed at settling once and for all the old argument over whether badgers infect cattle with bovine tuberculosis', but this was rarely reported. ${ }^{55}$ Backstage, MAFF had managed to form a broad consensus that culling using Cymag ('gassing') was the most humane way of dealing with the problem. However, media responses to the new policy were very different, with naturalists directly challenging the causal links drawn between badgers, $M$. bovis and cattle, while illegal gassing by farmers was presented as continuous with illegitimate gassing by Ministry officials. Rhetorics of the 'mass extermination' of badgers by authorities would have been particularly resonant for the post-war generations making up public audiences of the time. ${ }^{56}$ This coverage-present in newspapers across the political spectrum-continued into the pre- and post-publication controversy around the Zuckerman review and MAFF's abandonment of gassing in 1982. It was congruent with the broader convergence of the 'cultures of care' of conservation, environmentalism and animal rights discussed in Chap. 5. Moving into the 1980s and 1990s, bTB receded as a public issue, while wildlife politics (including badger persecution and fox hunting) became even more prominent. Further badger protection campaigning, including the adoption of media-friendly public spectacle (see Chap. 5, Fig. 5.4) was highly successful, culminating in the passing of the Badgers Act (1991), the Protection of Badgers Act (1992)—making it illegal to interfere with a sett without a government licence-and the further scaling back of culling for bTB control. ${ }^{57}$

The adeptness of badger advocates at setting media agendas continued in the early coverage of the RBCT experiment, sometimes referred to as the 'Krebs trial'. The National Federation of Badger Groups (NFBG, now Badger Trust) acquired a new media team: Dr Elaine King, a scientist who had trained at Woodchester Park, and PR specialist Trevor Lawson. ${ }^{58}$ Together, they mobilised King's own expertise to critique the new government plans, arguing it was based on 'weak science': 'The experiment 
is fundamentally flawed. In some of the target areas farmers are already killing badgers illegally and this will affect the outcome ... In other places landowners are denying access to land. And the traps cannot be guaranteed to catch all the badgers in an area. ${ }^{59}$ Backstage, the RBCT had been supported by the RSPCA, National Trust, British Veterinary Association (BVA) and NFU because they were persuaded that 'better evidence' was needed. ${ }^{60}$ Frontstage, farmers were more equivocal: 'Something has to be done. I don't know if it's badgers. You say thousands of badgers have been killed. Well, 31,000 cows have been killed as well. I just know this experiment is the best thing we've been offered. I'm imploring it all to go forward. It's affecting us all. ${ }^{61}$ Public debates were laying bare the growing differences between the epistemic communities of badger/bTB. While farmers cared for their cattle and their livelihoods, badger protection advocates were primarily concerned with the prospect of 'their' species being killed. Both found themselves at odds with policy-facing actors, whose cultures of care operated at a broader scale, concerned with (for example) the economic welfare of agricultural industries, preservation of landscape or minimising animal suffering.

When the emerging RBCT data suggested that badger culling might make bTB worse, the response from ministers was to shut down part of the experiment, while policymakers distanced themselves from the ISG. While the news was made public, it did not receive much attention, and MAFF continued planning for re-implementing culling, briefing to the press that this would happen. ${ }^{62}$ When the ISG eventually went public with their conclusions about culling and perturbation in 2007, the response from the NFU was one of shock and surprise: 'Sir John's [Bourne] report is a counsel of despair. We are not prepared to accept it.. ${ }^{63}$ Conservative commentators echoed these sentiments, describing the ISG's work as a 'bombshell' and citing bTB as another issue in which an increasingly beleaguered countryside was ignored by the 'metropolitan' interests allegedly dominating the Labour government. This narrative, also fostered by the burgeoning Countryside Alliance, placed bTB alongside the outlawing of hunting with hounds, animal health problems such as BSE and FMD, and environmental reforms of the EU's Common Agricultural Policy. ${ }^{64}$ These responses of shock, surprise and rejection of the ISG's research intensified when the following year Defra Secretary Hilary Benn reversed bTB policy, taking the scientists' advice, and decided not to cull: 'a move welcomed by environmentalists but condemned as a disaster by farmers' - widely interpreted as politically motivated. ${ }^{65}$ Even the Badger Trust appeared to be surprised by the ISG's findings. ${ }^{66}$ Given 
that MAFF specialists had been aware of 'badger movement' and 'recolonisation' since the 1970s, that ecologists had been researching perturbation and infectious disease since the mid-1990s, and that the ISG had been flagging the possibility for some years, the degree of surprise evidenced in media reporting suggests implies an widening gap between the 'backstage' and 'frontstage' of the policy debate.

The Return of Culling: Public Polarisation of bTB. In recent years, media debates over badgers and bTB seem to have undergone a significant-if possibly temporary-shift in visibility. During the pre-election year of 2009, levels of press coverage dipped as news agendas became occupied with mainstream politics. Since the incoming Coalition government announced their intention to return to badger culling (a policy agenda which has been progressively implemented ever since), these coverage patterns have changed. Rather than the long-standing pattern of episodic spikes, after 2010 press rose steeply to over 350 articles in 2013 , before returning to similar levels to the mid-2000s. While the knowledge controversy over badger/bTB has always had a public aspect to it, over the past ten years it has become significantly more public. So what happened? Why did this relatively obscure, chronic and complex policy problem suddenly become so much more newsworthy? In other words, why did we see 'peak badger' during 2013? Furthermore, what are the implications-for badger/bTB, for science-policy and for wider political debates-of wider media interest in the issue having faded almost as quickly as it appeared?

The post-2010 story of the return to badger culling has been one of progressive policy expansion, punctuated by deep uncertainties, persistent contestation of 'the science', many public protests and some spectacularly ridiculous news stories. While it was important to government that their policies were seen to be 'science-led' (albeit reliant on careful interpretations of the RBCT), we have seen increasingly strident criticisms of badger culling from scientists. These criticisms initially came from Lord Krebs and members of the ISG, but are now voiced across much wider scientific and policy networks. These public tensions were magnified when one of two expert panels appointed by Coalition ministers reached the conclusion that culling using 'free shooting' was neither humane nor effective, government ignored this advice, and members of the panel joined in scientific criticisms of government policy (see Sects. 6.3-6.4). As had happened after the Zuckerman report in 1980, the Krebs report in 1997 and the ISG report in 2007, once again an expert report had had the effect of opening up public debates, drawing media attention to the problem and 
creating further controversy. While these tensions have become much more public, they are continuous with the post-ISG situation of the mid2000 s, itself the outcome of a history of rivalries between the epistemic communities clustered around animal health and disease ecology policy.

As with most public knowledge controversies, a combination of 'push' and 'pull' factors has been responsible for moving the topic further into the public sphere. ${ }^{67}$ Epistemic rivalries acted as a strong 'push' for scientists connected with disease ecology to turn to public channels to make their case, particularly since 2007. In response, government animal bealth experts have changed their communications strategy, with the Chief Veterinary Officer (CVO) and Chief Scientific Adviser (CSA) taking on a new role:

... to provide information to those having to make decisions, including the public, and to ensure that the uncertainties around that information are made clear. When scientists start to stray into providing views about whether decisions based upon the evidence are right or wrong they risk being politicised..$^{68}$

In contrast with the ISG's broad ambitions to make recommendations that would directly establish bTB policy, this position neatly recircumscribes the boundaries of science and politics, putting the responsibility for decision-making firmly on the shoulders of politicians. However, this move may risk further politicising the problem. ${ }^{69}$

These 'backstage' drivers have been accompanied by a series of more visible 'frontstage' shifts, particularly relating to NGO campaigning, the alignment of the issue with partisan divides in British politics and media working practices. While badger protection groups have been active since the 1970s, it was not until 1996 that the NFBG registered as a charity, renaming itself Badger Trust in 2006. ${ }^{70}$ In 2014, the Trust acquired a new 'CEO', professional lobbyist Dominic Dyer, already involved in badger/ bTB in his previous position with the animal advocacy group Care for the Wild. ${ }^{71}$ In line with wider trends in the NGO sector, the Trust has professionalised significantly since 2010 , moving away from its roots in popular natural history and becoming more involved with fundraising and lobbying activities. ${ }^{72} \mathrm{~A}$ wider range of conservation and animal campaign groups have become involved with the badger/bTB debate, including the Save Me Trust, a wildlife charity founded and funded by the rock star Brian 
May. May has acted as the focus for a campaigning coalition known as Team Badger, which coordinates formal organisations with broader public activities, including protest marches and 'Wounded Badger Patrols' monitoring local culls. ${ }^{73}$ There has also been widespread illegal and semi-legal direct action conducted against the cull trials including protest camps, 'sabbing' of traps and equipment, and targeting of individuals. ${ }^{74}$ Since 2010 campaigners have also brought a series of court cases against the British and Welsh governments over culling policies: while these have been unsuccessful so far, they have enabled further public scrutiny of the scientific basis used to support policy. ${ }^{75}$

Despite its long-term entanglement with British conservation, environmental and animal politics, until quite recently badger/BTB has not been aligned clearly with the left-right partisan divides of British party politics. Early badger protection campaigners built broad alliances of support for legal changes and against culling which included both Conservative and Labour politicians. Similarly, while changes in bTB policy have been associated with transitions in governments, they have been equally symptomatic of rivalries and shifts within political parties as between them. This changed in 2008, when Labour minister Hilary Benn ruled out a culling policy. While his decision seems to have been driven by an openness to advice from a broad range of scientists and a reaction against the previous Blair government's pro-culling agenda, it was interpreted (by commentators on both left and right) in the context of increasingly politicised debates over agriculture, rurality, class and the environment. The 2010 election campaign saw Conservatives adopt a manifesto pledge to return to badger culling, and since 2011, Labour in opposition has actively campaigned against culling, working closely with NGO campaigners. ${ }^{76}$ Labour have now folded their opposition to badger culling into broader commitments to strengthening animal welfare policy. ${ }^{77}$ Conservative internal politics around badger/bTB have been equally complicated. By 2010, liberal modernisers (led by David Cameron) had adopted a pro-environmental stance, symbolised by his election promise to deliver the 'greenest government ever'. However, this was resisted by more traditional factions in the party, who-allied with right-wing press commentators and landowning/ agricultural interests - took an increasingly partisan position on environmental issues including climate change and regarded a return to badger culling as a key goal. ${ }^{78}$ During the Coalition government, both factions were needed to maintain party unity, making badger culling a relatively 
easy way of doing this (alongside commitments to a referendum on membership of the EU). As such the 2012 replacement of Caroline Spelman (a moderniser) in the role of Defra Secretary by Owen Paterson (a traditionalist) was an early signal of the shifting balance of power. This was particularly because Paterson was known to have long campaigned for badger culling, as well as being a climate- and Eurosceptic. ${ }^{79}$ While Paterson lost his job in 2014, the culling policy stayed and was further rolled out following the election of a Conservative government in 2015. In the 'frontstage' of bTB policy, the controversy has now settled into a politically partisan, binary debate for and against badger culling, in line with wider trends towards the public polarisation of environmental issues in the USA and UK. ${ }^{80}$

Making News. Together, these changes created many more stories appealing to 'news values' (factors which journalists and editors believe will appeal to audiences) ${ }^{81}$ After so many years of scientific research, arguments over interpretations of 'the evidence', briefing and counter-briefing, something was happening. Not only had politicians said culling was going to happen, but then it actually did, with two 'pilot' culls implemented in 2013 and more rolled out year on year. The increase in anti-cull campaigning activity and adoption of social media by all sides, carnivalesque protest marches (Fig. 7.4) and dramatic stories of intrepid animal activists and badger shooters chasing each other around the Gloucestershire countryside all drew journalistic attention, while the story was further sustained by a series of legal challenges. Controversy is itself a powerful news value, in which 'every action triggers a countermove by an opponent, with a series of sub-conflicts that become news again'-once a controversy like this becomes active in the media, nearly every story will generate another one. ${ }^{82}$ Finally, the badger/bTB story was increasingly populated by celebrities, whose actions and opinions are newsworthy in and of themselves. This was most obvious with Brian May, who wrote opinion pieces, attended protest marches and generally used his fame to bring the issue to public attention, up to and including his performance at the 2012 Olympic opening ceremony. He joined an increasingly long list of eminent but disgruntled scientists; 'telenaturalists' (including Bill Oddie, Chris Packham and David Attenborough); and other celebrities, all of whom drew print, broadcast and online media coverage far beyond the national press. This was not limited to anti-cull campaigning: celebrity chef Clarissa Dickson-Wright helpfully suggested that one solution to the badger 


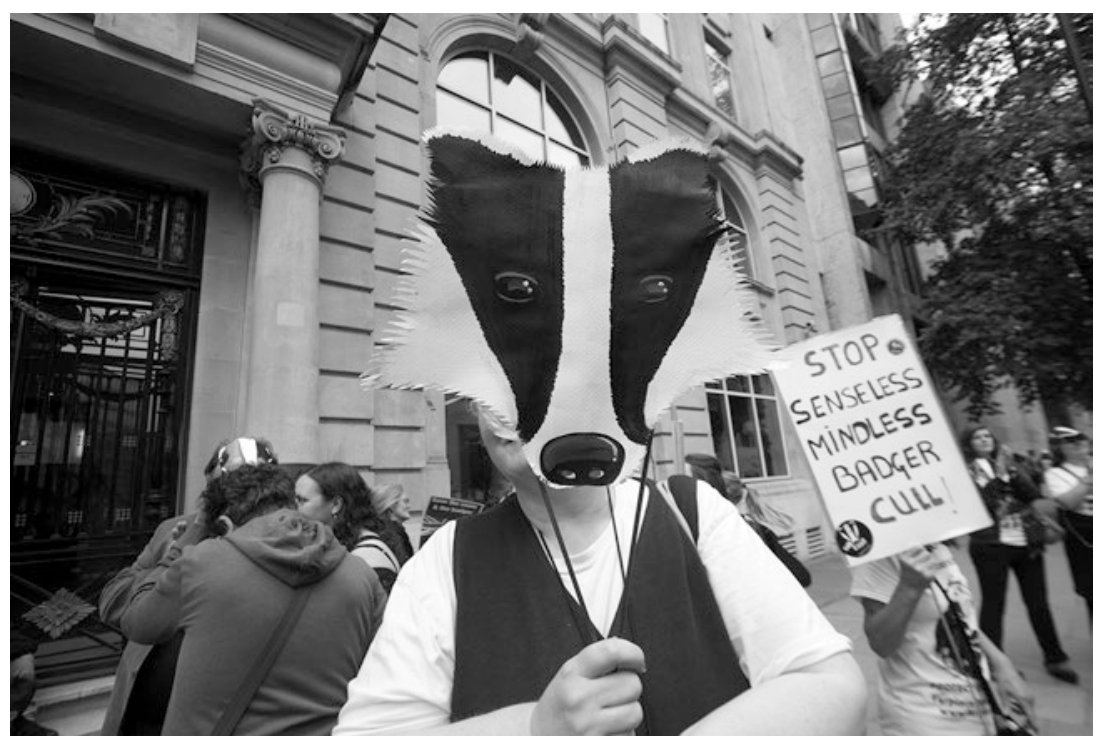

Fig. 7.4 Anti-cull demonstration, London, l June 2013. Credit: amer ghazzal/ Alamy Live News. Reproduced by permission of Alamy Stock Photos

problem could be to return to older practices of eating the animals, creating further outrage-cum entertainment from the story. ${ }^{83}$

The regular movement of politicians in and out of the role of Defra Secretary was always covered, but Owen Paterson's term of office (2012-2014) provided a particularly rich seam of material for journalists. Paterson was a colourful figure, outspoken on environmental and agricultural politics, with entertaining biographical details: '[he] kept two orphaned badgers named Bessy and Baz as pets while growing up'. ${ }^{84}$ Paterson oversaw a series of disasters at Defra, including a scandal in which horsemeat was found to be (illegitimately) present in UK food supplies, and disastrous flooding events. ${ }^{85}$ Notoriously, while being questioned about whether government was manipulating evidence relating to the pilot culls in 2013, Paterson stated, 'No, that's not right at all. The badgers have moved the goalposts. You're dealing with a wild animal! It's a wild animal, subject to the vagaries of the weather, and diseases and breeding patterns. ${ }^{86}$ From the perspective of someone familiar with badger/bTB (or wildlife in general) this statement makes sense, of a sort- 
Paterson seems to have been trying to express the deep unpredictability of working with wildlife, particularly badgers who, as we have seen, have repeatedly thwarted human 'management' by refusing to stay where they are put. However, this was lost on wider audiences, for whom the idea that badgers 'move the goalposts' (but politicians don't) was inherently ridiculous. The story hit social media with a bang, inspiring a series of satirical responses (including an online game: 'Owen Paterson's Badger Penalty Shootout') and reviving an '\#omnivoreshambles' social media hashtag invented specifically for Paterson. ${ }^{87}$

This episode highlights how the sudden explosion of badger/bTB into mainstream media was not just a consequence of the topic generating more stories than before, but also of transformations in mass media industries, working practices and what counts as 'news' as we have moved into the twenty-first century. These changes include the appearance and mass uptake of social and Internet-based media; the convergence and movement of 'traditional' formats (such as newspapers, television and radio) online; and an ongoing search for stable income models for commercial media. ${ }^{88}$ Communications scholars argue that these pressures have changed journalistic working practices, particularly in terms of the time and resources available to develop complex stories, and a tendency for coverage to become self-referential, more subject to 'hype', 'storms' and external manipulation than ever before. ${ }^{89}$ As discussed in the previous chapter, the movement of communications online has made the 'backstage' of policy and academic science more open and visible to the wider public sphere, while social media has facilitated direct interactions between journalists, news values and audiences, albeit with the specific groups of people using these platforms. ${ }^{90}$ In turn, this appears to have changed the news values of British media, increasing the importance of factors such as 'conflict', 'shareability' (on social media) and 'arresting audio-visuals'. ${ }^{91}$ Badger/bTB created a stream of striking visual stories (including badger masks, costumes, logos and a proliferation of political cartoons), lots of conflict, outrage and a good dose of ridiculousness. These stories, combined with a wider atmosphere of public polarisation around rural and environmental politics, made the issue perfect for a twenty-first-century media storm..$^{92}$ However, like any storm, this one seemed to blow itself out nearly as quickly as it had arrived. 


\subsection{A Passing Storm?}

In this chapter, we have explored the increasingly dramatic dynamics of the 'frontstage' of the badger/bTB controversy, over the period of the RBCT culling trial, as well as the return of badger culling since 2010 . We explored some basic contours of UK national newspaper coverage of the issue, which demonstrated how badger advocates have repeatedly been adept at setting media agendas, before and after the news of tuberculous badgers became public. This data also suggests that badger protection and bTB have become tightly linked together, and that together they were the subject of extremely high levels of media coverage between 2012 and 2014. Since the 1990s the issue has increasingly been framed in one of two mutually exclusive ways: bTB as an agricultural problem, or badger culling as an environmental risk. Within these framings, the centuries old British 'badger debate' continues, taking on new characteristics relating to infectious disease. As discussed in Chap. 1, these discourses are congruent not only with much older representations of the Good and Bad Badger, but with broader patterns in how people tend to talk and think about animals designated as 'pests'. ${ }^{93}$ Since 2010 the public controversy seems to have changed, with badger/bTB increasingly present in mid-market and tabloid newspapers and an extraordinary rise in overall coverage levels, which peaked in 2013 and then receded once more. While experts and evidence have always played a central role in these debates, 'science' is now routinely invoked in a simplistic way to support arguments both for and against badger culling, while some scientists have started actively campaigning, particularly against culling. While badger/bTB has always been political (with a small 'p') and fiercely contested by those involved, it was still a relatively obscure topic, covered intermittently. Since 2010 it has shifted to become a consistent topic of wider media interest. Until 2008, questions of badger persecution and/or what to do about bTB were topics of division and debate within political parties, with policy change as often precipitated by internal power shifts as the passing of government from one party to another. However, since Hilary Benn's decision to take the advice of the ISG and not cull, the issue has increasingly become politically partisan, with right-wing agendas lobbying for badger culling and left-wingers against. While the terms 'politicisation' and 'polarisation' might imply the sullying of a previously 'pure' scientific debate with a political mess, they can be better understood as the widening of differences between positions in the debate, the increasing identification of 
those positions with those of political parties and increasing levels of hostility expressed between opponents. The badger/bTB debate can perhaps be best understood as a British version of the highly polarised climate debates seen in the USA. As such, it forms part of wider trends toward the public polarisation and politicisation of environmental issues in the twentyfirst century. ${ }^{94}$

But what happened next? The wave of media coverage of badger $/ \mathrm{bTB}$ that crested in 2013 rapidly receded, returning to similar levels to those of the late 2000s. While it is likely that media attention will return to the topic in future-if, for example, a left-wing government enters power and turns bTB policy on its head yet again - this extraordinary peaking and fading still requires explanation. In part, the answer is obvious: it is the nature of media storms to abate, more so in today's fast-moving online world, driven by momentary social media clicks and 'likes'.$^{95}$ There is also an underlying tendency for news coverage of environmental issues to focus upon dramatic events and move on to something else before the complexities of the underlying problems can be explored. ${ }^{96}$ Novelty is yet another critical news value: when the pilot culls were expanded the same stories returned year after year, leading the ongoing 'YES!/NO!' narrative of the story to get stale. There has been a series of further changes since 2015 , potentially contributing to an abatement in the public controversy. The culling policy has hardened, transforming from 'pilots' to a 'rollout', with licences planned even in areas with little or no bTB; while at the same time the 'backstage' of bTB policy and scientific research has diversified and depolarised a little, as explored in the previous chapter. In the latest turn of the long story of the RSPCA's engagement with wildlife politics (see Chap. 5), the UK's oldest animal welfare charity has recently pulled back from an assertive anti-cull campaign running from 2011. While the RSPCA is still opposed to culling, the charity has undergone both internal and external criticism that it had become too 'political', resulting in changes in leadership and campaigning around wildlife politics. ${ }^{97}$ However, the major factor contributing to the receding of media interest in badger/ bTB is most likely to be the appearance of another, much bigger polarised political controversy, which continues to dominate news agendas at the time of writing: Brexit.

On one level, the 2016 UK referendum decision of Britain to withdraw from the EU has little to do with badger/bTB: it is entirely plausible that the former displaced the latter in media agendas simply through the sheer volume of Brexit news. The causes and consequences of Brexit are still 
being played out: it is already the subject of a plethora of academic and non-academic opinion and analysis. While central drivers of the Brexit debate (such as the politics of immigration) do not seem to map directly onto badger/bTB (although I note the significance of the badger as a British 'native' species), some shared factors drive both controversies. Most obviously, this can be seen in broader rural and environmental politics, and the rhetoric of 'marginalised rurality', ignored by urban elites and bureaucracies (whether located in London or Brussels). These have gathered strength over the past twenty years, driven by a cluster of environmental/agricultural problems including BSE, FMD, environmental reforms of the Common Agricultural Policy, fox hunting, supply chain dominance by retailers, regulation of pesticides, rural poverty and lack of infrastructure-and badger/bTB. ${ }^{98}$ The referendum outcome made visible wider urban-rural differences in Leave-Remain support, while a majority of farmers voted to Leave, despite the NFU supporting the Remain campaign and the potential devastation of their livelihood by the loss of EU subsidies. ${ }^{99}$ Key policy decisions were outcomes of tensions within political parties, particularly the attempts of moderniser David Cameron to maintain the support of right-wing Conservatives; but also tensions within Labour. Finally, both issues have become notoriously polarised, creating deep social divisions over specific points of contention, which appear to symbolise a broader constellation of political differences-including crucially the social roles of science, knowledge and expertise. At the time of writing, evidence is emerging suggesting that social media debates (about Brexit in Britain among others) have been subject to manipulation, creating public divisiveness and fostering mistrust in political systems. ${ }^{100}$ To purely speculate: was the 2012-2014 badger/bTB media storm a rehearsal or prefiguring of the Brexit debate yet to come?

Having explored the parallel development of the 'backstage' and 'frontstage' controversies over badger/bTB since the 1990s, several things are clear. In the earlier stages of the debate, explored in the first two parts of this book, the initially separate issues of badger protection and bTB have come together and moved apart several times, according to changes in the activities of animal advocates as well as shifts in bTB policy. Since the late 1990s, and particularly since the return to badger culling policies since 2010 , the two issues have become increasingly tightly linked. While badgers still draw media coverage by themselves, it is less so than in the past, while bTB is almost never discussed without mentioning badgers. Even though the 'backstage' of policymaking is far more visible to the 'frontstage' 
of the public sphere than ever before, in the case of badger/bTB, it seems that policy and public debates have become increasingly disconnected. During the 1970s, MAFF sought to head off public controversy by enrolling as wide a range of interests as possible in bTB policy processes. This was implemented explicitly by the creation of the Badger Consultative Panel, which, even if it had limited power, created a forum where key actors could engage directly with each other; and implicitly via the involvement of naturalists in MAFF's research and wider publics in a long-term project measuring bTB in badgers found dead on the roads. ${ }^{101}$ From the inception of the RBCT, these and other features of MAFF's previous policy approach were gradually abandoned, largely for reasons of cost, meaning that structures for direct engagement have been eroded, particularly for 'wildlife interests'. Increasingly the only forum available for all actors in badger/bTB to interact with each other has been via mass media: as we know from other cases of environmental controversy and policy formation, this removes opportunities for more subtle forms of negotiation and communication. ${ }^{102}$ This may also help to explain the increasingly tight focus of mass media on a highly dichotomised debate: to cull or not to cull, largely ignoring the complexities of how or when or the broader underlying causes of the problem. We have seen politicians on all sides benefiting from this process, as have campaigners claiming to speak on behalf of animals, environments and farmers. While much is still unclear about changing relationships between frontstage/backstage policymaking in the twenty-first century, policy scholars agree that imbalances or divergences between the two can contribute to policy failure and political problems. ${ }^{103}$ We will examine the implications of this disjunct-and what could possibly be done to bring the public and private aspects of badger/bTB policy back together-in the final chapter.

\section{Notes}

1. Ayres, Sandford and Coombes, 'Policy-Making "Front" and "Back" Stage'; Dunlop, 'Knowledge, Epistemic Communities and Agenda-Setting'.

2. Bourne et al., 'Bovine TB: The Scientific Evidence, Final Report of the Independent Scientific Group on Cattle TB', 14.

3. Whatmore, 'Mapping Knowledge Controversies'; Naylor et al., 'The Framing of Public Knowledge Controversies in the Media'; Amelia Sharman and Richard Perkins, 'Post-Decisional Logics of Inaction: The Influence of Knowledge Controversy in Climate Policy Decision-Making', 
Environment and Planning A: Economy and Space 49(10) (1 October 2017): 2281-99.

4. Agar, 'Transition'.

5. Motta, 'Social Disputes over GMOs'.

6. Kim, The Social Construction of Disease.

7. Lewenstein, 'From Fax to Facts'; Bucchi, Science and the Media; Cassidy, 'Evolutionary Psychology as Public Science and Boundary Work'.

8. Bruno Latour, Science in Action: How to Follow Scientists and Engineers through Society (Cambridge, MA: Harvard University Press, 1987).

9. Ayres, Sandford and Coombes, 'Policy-Making "Front" and "Back" Stage'; Hilgartner, Science on Stage.

10. Grant, 'Intractable Policy Failure'.

11. Because these newspaper digital archives are organised differently to the Nexis database the results are not directly comparable. Therefore, the results of these searches are depicted separately in Figs. 7.1 and 7.2.

12. Sources: Daily Mail Historical Archive (1896-2004); Daily Mirror Archive (1903-present); Guardian and Observer Archive (1791-2003); Independent Digital Archive (1986-2016); Telegraph Historical Archive (1855-2000); Times Digital Archive (1785-2011), excluding advertisements, crosswords, TV and racing listings.

13. See Sect. 3.1.

14. See Sect. 5.2.

15. See Sects. 3.3 and 5.3 .

16. Griggs and Howarth, 'Protest Movements, Environmental Activism and Environmentalism in the United Kingdom'.

17. Sect. 5.3 .

18. Source: Nexis-UK print media database: Daily Mail/Mail on Sunday, Daily/Sunday Mirror; Guardian/Observer; Independent/Independent on Sunday; Daily/Sunday Telegraph; Times/Sunday Times.

19. M. Djerf-Pierre, 'When Attention Drives Attention: Issue Dynamics in Environmental News Reporting over Five Decades', European Journal of Communication 27(3) (September 2012): 291-304.

20. Raymond Kuhn, Politics and the Media in Britain (Basingstoke: Palgrave Macmillan, 2007), 213-25.

21. Mike S. Schäfer, 'Taking Stock: A Meta-Analysis of Studies on the Media's Coverage of Science', Public Understanding of Science 21(6) (December 2012): 650-63.

22. M. C. Nisbet, 'Framing Science: A New Paradigm in Public Engagement', in Understanding Science: New Agendas in Science, ed. LeeAnn Kahlor and Patricia A. Stout (New York: Routledge, 2009), 40-67.

23. P. Wagner-Egger et al., 'Lay Perceptions of Collectives at the Outbreak of the HINl Epidemic: Heroes, Villains and Victims', Public Understanding of Science 20(4) (March 2011): 461-76. 
24. Maya Warrier, 'The Temple Bull Controversy at Skanda Vale and the Construction of Hindu Identity in Britain', International Journal of Hindu Studies 13(3) (2009): 261-78.

25. Van Zwanenberg and Millstone, 'BSE'; Mort et al., 'The Health and Social Consequences of the 2001 Foot \& Mouth Disease Epidemic in North Cumbria'; Döring and Nerlich, The Social and Cultural Impact of Foot and Mouth Disease in the UK in 2001.

26. S. Roberts, 'New NFU president issues rallying cry for "Team Agriculture"', Farmers Weekly, 23 February 2018.

27. Collins and Evans, 'The Third Wave of Science Studies'; Chloe Silverman, Understanding Autism: Parents, Doctors, and the History of a Disorder (Princeton: Princeton University Press, 2012).

28. Pile, 'A Load of Bloody Idiots'.

29. In an interview on the BBC's Countryfile in 2014, Princess Anne called for a return to gassing on animal welfare grounds; David Lowe, 'Princess Anne: Gas Is Much Nicer Way of Culling Badgers', Countryfile (BBC Television, 8 April 2014).

30. Anon., 'A diary of the badger cull-a marksmen tells his story', Western Morning News, 15 Oct. 2016, 20-21; see also Enticott, 'Techniques of Neutralising Wildlife Crime in Rural England and Wales'; G. Enticott, 'Public Attitudes to Badger Culling to Control Bovine Tuberculosis in Rural Wales', European Journal of Wildlife Research 61 (2015): 387; Naylor et al., 'The Framing of Public Knowledge Controversies in the Media'.

31. Robin Page, 'Country diary: Badgers are out of control', Daily Telegraph, 15 June 2013, 17. Farming claims of rising populations have recently been confirmed by new research; however, there seems to be a complicated, counter-intuitive relationship between population density and the epidemiology of bTB. See Judge et al., 'Abundance of Badgers (Meles Meles) in England and Wales'.

32. Wagner-Egger et al., 'Lay Perceptions of Collectives at the Outbreak of the HlNl Epidemic'.

33. Daniel Cressey, 'Scientists Track Badger-Cow Encounters to Understand Cattle TB', Nature News, 5 August 2016. One of these images is definitely staged (on closer inspection the animal is stuffed)-see the second picture in Brian May, 'This Cruel Badger Cull Is Pointless-and I Can Prove It, Says Queen Guitarist Brian May', Mail Online, 20 October 2012.

34. Counter to prevailing narratives, beyond the well-off and well-regulated Global North, neither TB nor bTB are 'solved' or a 'problem of the past'; for the history of (human) TB and public health, see McMillen, Discovering Tuberculosis. 
35. See Sect. 5.3.

36. Naylor et al., 'The Framing of Public Knowledge Controversies in the Media'.

37. Research on public attitudes to culling is still quite sparse. However, we do know that views are much less polarised and more subtle than is generally assumed; see Enticott, 'Public Attitudes to Badger Culling to Control Bovine Tuberculosis in Rural Wales'; Price et al., 'From Contradiction to Contrast in a Countryside Conflict'; OPM Group, 'Defra Bovine TB Citizen Dialogue. Cross-Cutting Summary’ (London: Defra, April 2015).

38. Price, Thinking through Badgers; Phoenix, 'Local Understandings of Bovine Tuberculosis (Working Title)'.

39. M. Engel, 'Killing Zones: Ethnic cleansing is to be attempted in the English counties', The Guardian, 24 October 1998, 23.

40. Patrick Bateson, 'Culling Badgers Could Increase the Problem of TB in Cattle|Letters', The Observer, 14 October 2012, sec. Global.

41. Damian Carrington, 'Record 32,000 badgers shot in annual cull; Scientists accuse officials of cherry-picking data to defend disease-control scheme', The Guardian, Environment section, 18 December 2018.

42. S. Cowell, 'Call off the Cull', Daily Mirror, 1 September 2016, 12.

43. H. Weathers, 'Mother badgers are snared in rusty cages, parted from their screaming cubs and shot in the head', Daily Mail, 3 June 2000, 11; BBC, 'Anger after Badger Found Shot in Gut', BBC News Online, 23 September 2014, sec. Somerset.

44. L. Gray, 'Jews angered by star's claim that badger cull is genocide', Daily Telegraph, 11 September 2013, 15; Zoe Williams, 'Chris Packham: It has a psychopathic element, taking pleasure from killing', Guardian, 11 September 2015.

45. See also the BBC Trust's recent review of their rural coverage: Helen Hancock, 'BBC Trust Impartiality Review: BBC Coverage of Rural Areas in the UK', A BBC Trust report, June 2014.

46. Cronin, Art for Animals.

47. Rebecca Sandover, Samuel Kinsley and Stephen Hinchliffe, 'A Very Public Cull-The Anatomy of an Online Issue Public', Geoforum 97 (1 December 2018): 106-18; Clare Saunders and Caroline Keenan, 'Conflict Framing in the Control of Bovine Tuberculosis' (journal article, in prep.); Mehmet Mehmet and Peter Simmons, 'Kangaroo Court? An Analysis of Social Media Justifications for Attitudes to Culling', Environmental Communication 12(3) (September 2016): 370-86; Price et al., 'From Contradiction to Contrast in a Countryside Conflict'.

48. For accessible overviews of science, environment and media research, see Anders Hansen, 'Communication, Media and the Social Construction of the Environment', in The Routledge Handbook of Environment and 
Communication, ed. Anders Hansen and Robert Cox (New York: Routledge, 2015), 26-38; A. Anderson, Media, Environment and the Network Society (Cham, Switzerland: Springer, 2014).

49. I. Petersen, H. Heinrichs and H. P. Peters, 'Mass-Mediated Expertise as Informal Policy Advice', Science, Technology \& Human Values 35(6) (August 2010): 865-87; A. M. Scheu et al., 'Medialization of Research Policy: Anticipation of and Adaptation to Journalistic Logic', Science Communication 36(6) (September 2014): 706-34; Dunlop, 'Knowledge, Epistemic Communities and Agenda-Setting'.

50. Stephen Hilgartner and C. L. Bosk, 'The Rise and Fall of SocialProblems-A Public Arenas Model', American Journal of Sociology 94(1) (1988): 53-78.

51. See Chaps. 3,4 and 5 for full accounts of the controversy between the 1960s and 1990s.

52. Anon., 'Ministry Seeks Powers to Gas Ailing Badgers', Times, 6 February 1975; 'Peart Cleared of Badger Cruelty Charge', Daily Telegraph, 29 January $1975,3$.

53. G. Brown, 'Gassing of Badgers Paying Off-Agriculture Correspondent', Daily Telegraph, 10 January 1978, 6.

54. Alongside Murray's ongoing media appearances, natural history books reinforced earlier accounts of badger persecution. The animal star of one of these fell victim to gassing just before MAFF announced their culling policy-anon., 'Death in a Sussex Gas Chamber', Sunday Telegraph, 13 July 1975, 13; Malins, Bully os the Badger.

55. G. Lakeman, 'Ministry Plans Mass Gassing of Badgers', Daily Telegraph, 28 July $1975,3$.

56. Anon., 'Ministry Gets Rap for "Blitz" on Badgers', Daily Mail, 23 Dec. 1980, 9. While Cymag was a different compound to that used during the Holocaust (Zyklon B), both work by releasing deadly hydrogen cyanide gas.

57. R. J. Delahay et al., 'Managing Conflict between Humans and Wildlife: Trends in Licensed Operations to Resolve Problems with Badgers Meles Meles in England', Mammal Review 39(1) (January 2009): 53-66.

58. Dr King is now Director of Wildlife Link, the coalition group of NGOs cited by Peter Melchett as instrumental in aligning conservation and animal advocacy during the early 1980s; Melchett and Brodie, Peter Melchett Interviewed by Louise Brodie; Elaine King, 'Elaine King|LinkedIn', 2018.

59. N. Fielding, 'Why Are They Slaughtering Our Badgers?' Mail on Sunday, 2 May 1999, 28.

60. Interviews with RSPCA scientific officer, 28/01/10; ISG member, $17 / 03 / 10$. 
61. M. Engel, 'Killing Zones: Ethnic Cleansing Is to be Attempted in the English Counties', Guardian, 24 October 1998.

62. See Sect. 6.3.

63. Charles Clover, 'Badger Cull "Off" as Study Concludes It Would Make TB Worse', Daily Telegraph, 16 June 2007, 14.

64. Clive Aslet, 'It's Up to You Now, Gordon', Daily Telegraph, I Aug. 2007, 21; see also work on discourses of 'marginalised rurality' during the 2001 FMD outbreak by K. Bickerstaff, P. Simmons and N. Pidgeon, 'Situating Local Experience of Risk: Peripherality, Marginality and Place Identity in the UK Foot and Mouth Disease Crisis', Geoforum 37(5) (2006): 84458. On the 'prohibition' of hunting by New Labour, see Marvin, 'English Foxhunting'. On Euroscepticism, environmental issues and rural politics in the UK, see Michael M. Bell, Sarah E. Lloyd and Christine Vatovec, 'Activating the Countryside: Rural Power, the Power of the Rural and the Making of Rural Politics', Sociologia Ruralis 50(3) (June 2010): 205-24; Matthew Reed, “"This Loopy Idea”: An Analysis of UKIP's Social Media Discourse in Relation to Rurality and Climate Change', Space and Polity 20(2) (May 2016): 1-16.

65. D. Derbyshire, 'Farmers' Fury as Badger Cull to Fight Cattle TB Is Called Off', Daily Mail, 5 July 2008.

66. Fiona MacRae, 'Cull Badgers to Protect Cattle from TB Threat', Daily Mail, 23 Oct. 2007, 4.

67. Bucchi, Science and the Media; Cassidy, 'Evolutionary Psychology as Public Science and Boundary Work'.

68. Boyd, 'Making Science Count in Government', 1. It was around this time that Defra started using social media for public communication, including enrolling their Chief Scientist and CVO to make the case for badger culling.

69. The recent Godfray review makes similar recommendations re science and policy: Godfray et al., 'A Strategy for Achieving Bovine Tuberculosis Free Status for England'. However, for the potential pitfalls of this move see also Daniel Sarewitz, 'How Science Makes Environmental Controversies Worse', Environmental Science \& Policy 7(5) (October 2004): 385-403.

70. Charity Commission, 'Charity Details: National Federation of Badger Groups', Registered Charities in England and Wales, 2006; Charity Commission, 'Charity Details: Badger Trust', Registered Charities in England and Wales, 2016.

71. L. Gray, 'Strip Badger Cull Farmers of Organic Status', Daily Telegraph, 21 September 2012; Lancashire Badger Group, 'Badger Trust's New CEO Is Leading Anti-Cull Spokesman', Lancashire Badger Group (blog), 24 February 2014. 
72. Hilton et al., The Politics of Expertise.

73. See also www.save-me.org.uk and http://newsl.teambadger.org, alongside Charity Commission, 'Charity Details: The Save Me Trust', 2017.

74. See http://badgeractionnetwork.org.uk/; Price, Thinking through Badgers; Phoenix, 'Local Understandings of Bovine Tuberculosis (Working Title)'.

75. Patrick Bishop, 'Badgers and Bovine Tuberculosis: The Relationship between Law, Policy and ScienceBadger Trust v Welsh Ministers [2010] EWCA Civ 807', Journal of Environmental Law 24(1) (1 March 2012): 145-54; Martin Lodge and Kira Matus, 'Science, Badgers, Politics: Advocacy Coalitions and Policy Change in Bovine Tuberculosis Policy in Britain', Policy Studies Journal 42(3) (August 2014): 367-90; Enticott, 'Public Attitudes to Badger Culling to Control Bovine Tuberculosis in Rural Wales'; Steven P. McCulloch and Michael J. Reiss, 'Bovine Tuberculosis and Badger Control in Britain: Science, Policy and Politics', Journal of Agricultural and Environmental Ethics 30(4) (1 August 2017): 469-84.

76. Damian Carrington, 'Pilot Badger Culls Get Go-ahead in England', Guardian, 15 December 2011, 19; Brian May, 'Vegetarian Rock Stars Don't Vote Tory. I Did. But I'll Never Vote for Cameron after His Bloody Badger Cull', Mail Online, 25 August 2012.

77. See https://labour.org.uk/issues/animal-welfare-plan/.

78. Carter and Clements, "From "Greenest Government Ever" to "Get Rid of All the Green Crap"'.

79. C. Brooker, 'Paterson Finally Prods Defra into Action on bovine TB', Sunday Telegraph, 18 Dec. 2005; B. Brogan, and R. Winnett, 'We Want Our Country Back from Europe: Interview', Daily Telegraph, 8 Dec. $2012,16$.

80. Lucas and Warman, 'Disrupting Polarized Discourses'.

81. Tony Harcup and Deirdre O'Neill, 'What Is News? News Values Revisited (Again)', Journalism Studies 18(12) (2 December 2017): 1470-88.

82. Peter Vasterman, 'Introduction', in From Media Hype to Twitter Storm, News Explosions and Their Impact on Issues, Crises, and Public Opinion (Amsterdam: Amsterdam University Press, 2018), 18. See also DjerfPierre, 'When Attention Drives Attention: Issue Dynamics in Environmental News Reporting over Five Decades'.

83. B. Reade, 'NOW CLARISSA'S BADGER BASTING', Daily Mirror, 27 September 2012, 25.

84. J. Shute, 'Between the badger and the barrel of a gun', Daily Telegraph, 31 August 2013, 25; also Barkham, Badgerlands, chap. 15.

85. For 'horsemeatgate' see Yasmin Ibrahim and Anita Howarth, "Contamination, Deception and "Othering": The Media Framing of the Horsemeat Scandal', Social Identities 23(2) (March 2017): 212-31. 
86. BBC, 'Badgers "moved Goalposts" in Cull'.

87. Barkham, Badgerlands, 317-42; Price, Thinking through Badgers, 21323; Political Scrapbook, 'Best of the Badger: The 5 Funniest Responses to Paterson's Own Goal', Political Scrapbook, 10 October 2013.

88. Vasterman, ed., From Media Hype to Twitter Storm; Anderson, Media, Environment and the Network Society.

89. H. Riesch, 'Changing News: Re-Adjusting Science Studies to Online Newspapers', Public Understanding of Science 20(6) (August 2010): 771-77; John Wihbey, 'Journalists' Use of Knowledge in an Online World', Journalism Practice 11(10) (November 2016): 1267-82; Joshua A. Tucker et al., 'Social Media, Political Polarization, and Political Disinformation: A Review of the Scientific Literature', SSRN Scholarly Paper (Rochester, NY: Social Science Research Network, 19 March 2018); Vasterman, ed., From Media Hype to Twitter Storm.

90. Aeron Davis, 'New Media and Fat Democracy: The Paradox of Online Participation', New Media \& Society 12(5) (November 2009): 745-61; Baym and boyd, 'Socially Mediated Publicness'; Jonathan Mellon and Christopher Prosser, 'Twitter and Facebook Are Not Representative of the General Population: Political Attitudes and Demographics of British Social Media Users', Research o Politics 4(3) (1 July 2017).

91. J. H. Lee, 'News Values, Media Coverage, and Audience Attention: An Analysis of Direct and Mediated Causal Relationships', Journalism \& Mass Communication Quarterly 86(1) (March 2009): 175-90; Harcup and O'Neill, 'What Is News?'

92. Cassidy, 'Badger-Human Conflict'. For the formation of 'issue publics' around badger/bTb in social media see Sandover, Kinsley and Hinchliffe, 'A Very Public Cull'.

93. Knight, 'Introduction'; Cassidy, 'Badger-Human Conflict'.

94. Dan M. Kahan et al., 'The Polarizing Impact of Science Literacy and Numeracy on Perceived Climate Change Risks', Nature Climate Change 2 (May 2012): 732-35; Lucas and Warman, 'Disrupting Polarized Discourses'.

95. Vasterman, ed., From Media Hype to Twitter Storm.

96. Djerf-Pierre, 'When Attention Drives Attention'.

97. J. Starkey, 'RSPCA backtracks on plan to shame farmers who take part in badger cull', The Times, 18 October 2017, 4 .

98. Reed, 'This Loopy Idea'; Bickerstaff, Simmons and Pidgeon, 'Situating Local Experience of Risk'.

99. BBC, 'Farmers' Union Backs Staying in EU', BBC News Online, 18 April 2016, sec. UK; Philip Clarke, 'Farmer Support for Brexit as Strong as Ever, FW Poll Reveals', Farmers Weekly, 22 December 2017. 
100. Tucker et al., 'Social Media, Political Polarization, and Political Disinformation'; Damian Maye et al., "'Present Realities” and the Need for a "Lived Experience" Perspective in Brexit Agri-Food Governance', Space and Polity 22(2) (4 May 2018): 270-86; Will Jennings and Martin Lodge, 'Brexit, the Tides and Canute: The Fracturing Politics of the British State', Journal of European Public Policy 26(5) (31 May 2018): $1-18$.

101. Grant, 'Intractable Policy Failure'; Overy and Tansey, A History of Bovine TB c.1965-c. 2000.

102. Cassidy, 'Evolutionary Psychology as Public Science and Boundary Work'; Libby Lester and Brett Hutchins, 'The Power of the Unseen: Environmental Conflict, the Media and Invisibility', Media Culture and Society 34(7) (October 2012): 847-63.

103. Ayres, Sandford and Coombes, 'Policy-Making "Front" and "Back" Stage'.

Open Access This chapter is licensed under the terms of the Creative Commons Attribution 4.0 International License (http://creativecommons.org/licenses/ by $/ 4.0 /)$, which permits use, sharing, adaptation, distribution and reproduction in any medium or format, as long as you give appropriate credit to the original author(s) and the source, provide a link to the Creative Commons licence and indicate if changes were made.

The images or other third party material in this chapter are included in the chapter's Creative Commons licence, unless indicated otherwise in a credit line to the material. If material is not included in the chapter's Creative Commons licence and your intended use is not permitted by statutory regulation or exceeds the permitted use, you will need to obtain permission directly from the copyright holder.

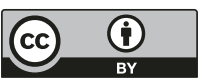

